\title{
A Test of Managerial Discretion and Market Efficiency in the Public Venture Capital Industry
}

\author{
Hannah Rozen \\ Fairleigh Dickinson University \\ Sarah Hertz \\ Empire State College \\ State University of New York
}

In the public venture capital industry, firms are owned by institutional investors and other stakeholders possessing inside information that may lead to the leakage of company news before an event actually occurs. Using an event study, we examine the potential effect insiders have on the market through stock trading. We study trading volume, absolute percent changes in trading volume and percent changes in price five days prior and post an important news event. In cases where there is a large increase in trading volume before an event is reported in the news, it is presumed that news leakage has occurred. Furthermore, it is important to analyze whether share prices impound this information rendering the market efficient, or whether prices take time to "catch up" in which case the public venture capital market would be considered only semi-strong efficient.

\section{INTRODUCTION}

Insiders are defined as officers, directors, other key employees, and shareholders holding more than ten percent of any equity class. All of these are prohibited from trading on undisclosed "material" information. To be legal, insiders only have to report their holdings within the first ten days of the month following the month of the trade (Persons, 1997). Insider transactions are published on the SEC's online insider trading report. Shortly afterwards, the information is published in the Wall Street Journal and other publications. Chang and Suk (1998) find that there is a significant share price reaction even after the announcement in the Wall Street Journal. They suggest that the SEC online report is only read by a small number of investors, whereas the Wall Street Journal is read by a much larger number of investors.

News leakage occurs when management or large investors "leak" that an event is about to happen. Due to the fact that these individuals often own large blocks of shares and options, they will often trade based on this information. They may do so legally, provided they follow insider trading guidelines which requires reporting their trades to the SEC. Many investors and traders use this information to identify companies with investment potential, assuming that if those in the know are buying the stock, their strategy should be replicated. ${ }^{1}$ In the United States, new information is only gradually reflected in stock prices and there is leakage of price-sensitive information. Dedman (2004) finds that stock prices start 
adjusting five days before a profit warning and up to five days after. When a market fully adjusts to incorporate information available to all stakeholders, it is considered to be an efficient market.

\section{Institutional Setting: The Public Venture Capital (VC) Industry ${ }^{2}$}

Venture capitalists raise funds in order to invest in young, promising companies. Through a combination of due diligence, intensive monitoring and direct assistance, the venture capitalist seeks to create companies that will eventually go public. The VC industry in the U.S. continues to grow. According to the National Venture Capital Association, in 2014 alone, VCs raised almost $\$ 50$ billion from 254 different funds. This was the largest amount raised by VCs since the year 2000 .

The VC generally follows a three-stage lifecycle. First, it pre-screens business plans in order to select promising candidates. VC's will often peruse hundreds of plans before settling on a few companies to champion (Gompers, 1994). Companies most likely to benefit from the capital and services of a VC are those with few tangible assets to pledge as collateral, and where information asymmetries are highest, such as high-tech and biotechnology companies. In such cases, VC expertise in guiding the company and in presenting it to the public is most needed. Second, the VC nurtures and monitors the investment, both with staged capital infusions, and managerial assistance. During this time, VCs continue to periodically gather information and maintain the option to discontinue funding projects which display little probability of going public (Gompers, 1995). Finally, the VC harvests its investment. The VC aims to exit its investment by taking the company public through a successful IPO, but it often is forced to exit either by merger or acquisition, a sale, or, commonly (about sixty percent of the time), a liquidation. It is in this last stage of harvesting that the differences between VC-backed companies and non-VC-backed companies becomes most apparent. In almost every industry in the U.S., the venture-backed IPO's reached the public market sooner and more profitably than the non-venture-backed group (Lerner and Watson, 2008). Wellknown VC successes include Microsoft, Intel, Staples and Starbucks, amongst many others.

A VC firm may be organized in several ways: it may be a publicly traded VC, a captive subsidiary of a large bank or corporation, a small business investment company or a private limited partnership (Barry, 1994). The most common, and, therefore, the most focused upon in the relevant literature, has been the limited partnership. In a limited partnership VC, the venture capitalists (usually between two and ten) are the general partners who initiate and control the activities of a number of funds. Investors, generally institutional investors, are considered limited partners and may monitor the progress of the fund they are invested in, but are not involved in the day to day activities of the fund. A partnership agreement is signed at the fund's inception which clearly defines the compensation over the fund's life. Typically, general partners earn a percent of the funds' capital or assets as an annual management fee plus a percent of the profits to be paid out as investment returns are realized. This mechanism is set so as to align the incentives of the general and limited partners, similar to a compensation based pay structure.

Though academic researchers have rarely examined publicly traded venture capital firms, it is evident from the little written on the subject that these firms are of similar size and structure to their much more popular limited partnership counterparts (Brophy and Gunther, 1988; Gompers, 1994; Cumming and Johan, 2008). The lack of attention to publicly traded VC's is largely due to a lack of data. This is because there are very few (approximately fifteen) VC's that choose to incorporate, and those that are incorporated do not list most of their financial data on public databases such as CRSP or Compustat. Given the similarity between publicly traded VC's and privately held VC's, examining the public VC industry is useful not only in its own right but also in shedding light on the limited partnership VC industry which controls an ever increasing share of invested capital. Additionally, much can be learned by the comparisons that can be drawn between the public VC industry and other industries which have a large percentage of their net assets in investment securities.

The reason there is such a great difference in number between private and public VC firms (private VC firms number in the thousands, while there are scarcely fifteen publicly traded venture capital firms), may be due to the fact that there are significant disincentives and very few incentives for a venture capital firm to "go public" in the United States. ${ }^{3}$ 
Public VC firms were restricted from transactions with their portfolio companies and investors under the Investment Company Act of 1940. This changed in 1980, when the Small Business Investment Act allowed public VC firms to incorporate as Business Development Companies (BDC's) that could invest in a similar manner to limited partnership VC's. However, Public VC's are subject to high costs - either by paying double taxation on corporate profits, or by trying to avoid it by paying high BDC registration costs. Incorporating as a public partnership also places limitations on the firm, since there is no organized market to trade their shares, and money invested is, therefore, highly illiquid. Additionally, high broker and underwriter fees must be paid. Public VC's also must absorb costs of complying with financial statement regulations, as would any public company. Due to these factors, VC's in the United States generally do not incorporate, and, since there are many institutions with sizeable funds available for VC investing, they generally do not need to.

On the other hand, incorporating provides two important benefits, amongst others. First, since profits can be re-invested as retained earnings, investors can avoid the capital gains tax. Second, investors are not only institutions but also individuals who may not be as myopic as some investor institutions (for example, pension funds). A public $\mathrm{VC}$ fund provides executives with the flexibility to hold on to the best performing portfolio companies as long as it takes to yield their optimal returns.

\section{LITERATURE REVIEW: MARKET EFFICIENCY}

The theory of market efficiency, first introduced by Eugene Fama in the 1960's, has been accepted in the finance literature for decades. The theory states that asset prices, and the market as a whole, reflect all available information and therefore trade at fair market value. As such, the typical investor has no way to make a profit since it is unrealistic for investors to either purchase undervalued stock or sell overvalued stock. Neither technical analysis (study of past stock prices to predict future stock prices) nor fundamental analysis (study of qualitative and quantitative factors to evaluate a security) would be helpful in assisting investors to outperform the market. The efficient market hypothesis (EMH) is closely related to the random walk hypothesis, popularized by Burton Malkiel (1973) in his book titled "A Random Walk Down Wall Street." The hypothesis states that stock market prices are random and unpredictable, and therefore cannot be predicted.

In acknowledgement of the fact that investors often are able to make a market profit, Fama's influential work (1970), provided three subsets of the EMH theory: weak form, semi-strong form, and strong form. The distinction among the three forms lies in the amount of information reflected in the price: the weak form asserts that security prices incorporate all past security market information and historical data; the semi-strong form believes that security prices fully reflect all publicly known information; the strong form states that all information, both publicly and privately known, is incorporated into the current security price. For the weak form of the EMH, this would imply that technical analysis has no predictive value. For the semi-strong form, it would imply that on average, fundamental analysis will not earn positive returns. For the strong form, even insider information is not helpful in predicting security prices.

The vast majority of the literature agrees that markets are efficient to some degree, at least in the weak form (see, for example, Fama (1970) and Chan et.al. (1997) who find that world equity markets are weak form efficient, and T'oth and Kert'esz (2006) who document increasing efficiency in the New York Stock Exchange), and thus we often take it as a predicated assumption. Ball $(1994,1995,2009)$ affirms that despite the limitations of the $\mathrm{EMH}$, the theory contributes greatly to our understanding of the markets. As he so aptly states, "The impact of the theory of efficient markets has proven to be durable, and seems likely to continue to be so, despite its inevitable and painfully obvious limitations" (Ball, 2009). Schwert (2003) notes that often the identification of anomalies in the literature prompts investors to trade on it, thereby making it irrelevant for future sample periods: "But even if the anomalies existed in the sample period in which they were first identified, the activities of practitioners who implement strategies to take advantage of anomalous behavior can cause the anomalies to disappear (as research findings cause the market to become more efficient)." Event studies are often used to determine how 
quickly market prices adjust and are therefore used to study market efficiency. Stock prices are expected to reflect the true value of the firm as they are assumed to reflect the discounted value of all future cash flows and incorporate all relevant information. "Event study method is a powerful tool that can help researchers assess the financial impact of changes in corporate policy" (McWilliams and Siegel, 1997).

In an event study, stock prices are examined in a window prior to and subsequent to an "event" such as an earnings announcement, mergers and acquisitions, and other corporate announcements. The returns are then analyzed to determine whether the event produced abnormal returns as a result of the event. The abnormal returns of the day of the event are analyzed, representing the difference between the actual returns of the day and the average return. When doing an event study, it is important to have a pre-event base period free of information so that interpretation of findings will be clearer and without contamination of other information.

The seminal work by Fama, Fisher, Jensen and Roll (1969) used the event study methodology to study stock splits and found that the announcement of the split had more of an impact on the stock price than the split itself. Ball and Brown (1968) and Ball (1978) studied the market reaction to earnings announcements, and also found that most of the price adjustment is prior to the actual event; the postannouncement risk adjusted abnormal returns are systematically non-zero. Watts (1978) studied the response to quarterly earnings announcements and found statistically significant abnormal returns. The stock price reaction to the announcement of cash dividend is studied by Charest (1978) shows significant non-zero abnormal returns in the months following the dividend changes.

Criticism to the EMH comes largely from the subset of behavioral economics (which arose in the 1990's) and psychologists who claim that human behavior does not always follow the "rational man" theory and individuals often buy overvalued stocks due to biases. In addition, transaction costs and liquidity can have an impact on the validity of the EMH. Different market anomalies are studied more recently to explain the instances where the market seems to be more driven by behavioral finance. To bridge the gap between proponents of EMH and behavioral finance, Lo (2004) proposes an adaptive markets hypothesis $(\mathrm{AMH})$ where market efficiency can vary continuously over time and across markets. Yet, despite the growing branch of behavioral finance, many still believe that the EMH is still relevant. For example, Fama (1998) surveys empirical work on event studies and concludes that market efficiency is prevalent in the long run, and that most return anomalies disappear. Malkiel (2003) also believes that EMH continues.

\section{THE STUDY}

In this study, firms are largely owned by stakeholders possessing much inside information. Therefore, we look at news leakage by studying changes in trading volume and absolute changes in price around news announcement dates.

We study the potential effect insiders have on the market through stock trading. Since, under the assumption of an efficient capital market, a firm's asset price immediately reflects the economic impact of an event, if there is a lead or lag in price change surrounding an event, the market is not considered entirely efficient. We examine trading volume, absolute percent changes in trading volume and percent changes in price five days prior and five days post an important news event following the methodology of Brown and Warner (1985). In cases where there is a large increase in trading volume before an event is reported in the news, it is presumed that news leakage has occurred. Since a large proportion of the firm is owned by insiders and institutions who have close access to insiders, it is possible that trading before the news event is performed by insiders. If trading occurs before an event takes place, it is important to analyze whether share prices impound this information rendering the market efficient, or whether prices take time to "catch up" in which case the public VC market would be considered only semi-strong efficient. We present an overview and graphical evidence of news leakage. We leave more rigorous testing as a topic for future research. 


\section{DATA COLLECTION AND SAMPLE}

We employ a sample of nine US publicly traded venture capital firms for the years 1998 to 2008. The list was composed using Hoover's database, The Wall Street Journal Online and by conducting searches on internet search engines using the definition of small business development companies under the Investment Company Act of 1940.

For our analysis on news leakage, we obtained trading volume and share prices from MergentOnline and CRSP. Daily announcement information of the publicly traded VC investments was gathered from financial newspapers, magazines and financial databases such as The Wall Street Journal Online, Dow Jones Interactive, MergentOnline and Lexis Nexis. Data was then cross-checked against public reports of the $\mathrm{VC}$ fund in order to include only reports that provided new information.

\section{RESULTS}

Due to the nature of the public VC industry, in that it is largely owned by institutional and inside investors, it is reasonable to believe that many owners are informed of news events before they actually occur. It is also reasonable to believe that they trade based on this information. We test whether this is the case.

Below, in Table 1, we display the mean trading volume of firm shares five days before and five days after a newsworthy event takes place. One can see that the most trading surrounding a news event takes place one day prior to the event, rather than on or after the day the news is released.

TABLE 1

VOLUME, YEARS $1998-2008, \mathrm{~N}=63$

\begin{tabular}{|l|l|l|l|l|}
\hline Variable & Mean & Std. Deviation & Min & Max \\
\hline Volt-5 & 195242 & 338021 & 432 & 1722946 \\
\hline Volt-4 & 198175 & 377200 & 100 & 2199983 \\
\hline Volt-3 & 209520 & 405887 & 800 & 2491772 \\
\hline Volt-2 & 168219 & 299348 & 200 & 1700530 \\
\hline Volt-1 & 427899 & 1173971 & 225 & 6085693 \\
\hline Volt=0 & 237176 & 489965 & 200 & 2964598 \\
\hline Volt+1 & 216852 & 368118 & 455 & 1941085 \\
\hline Volt+2 & 219776 & 396098 & 400 & 2211573 \\
\hline Volt+3 & 355424 & 1513572 & 335 & 1100007 \\
\hline Volt+4 & 259706 & 657100 & 600 & 4443179 \\
\hline Volt+5 & 294656 & 671749 & 200 & 2681617 \\
\hline
\end{tabular}

Figure 1 displays this information graphically. 


\section{FIGURE 1}

\section{VOLUME AROUND NEWS EVENT}

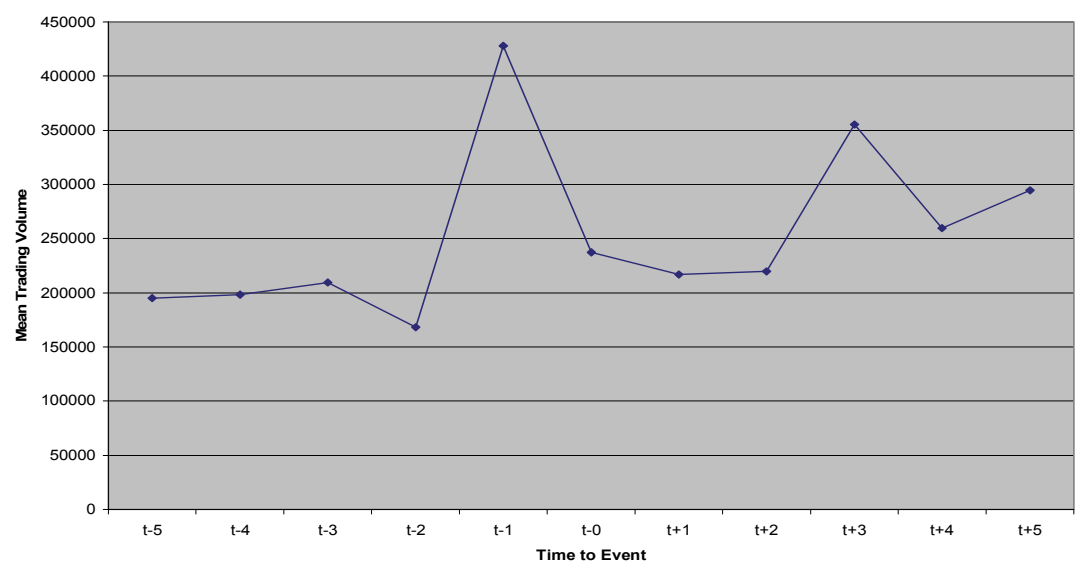

In Figure 2, rather than presenting the change in raw volume, we present the absolute percent change in trading volume surrounding a news event. Once again, it is clear that the greatest change in trading volume takes place a day before news is released, with more minor changes taking place on and afterwards.

\section{FIGURE 2}

\section{PERCENT CHANGE IN MEAN TRADING VOLUME AROUND NEWS EVENT DATE}

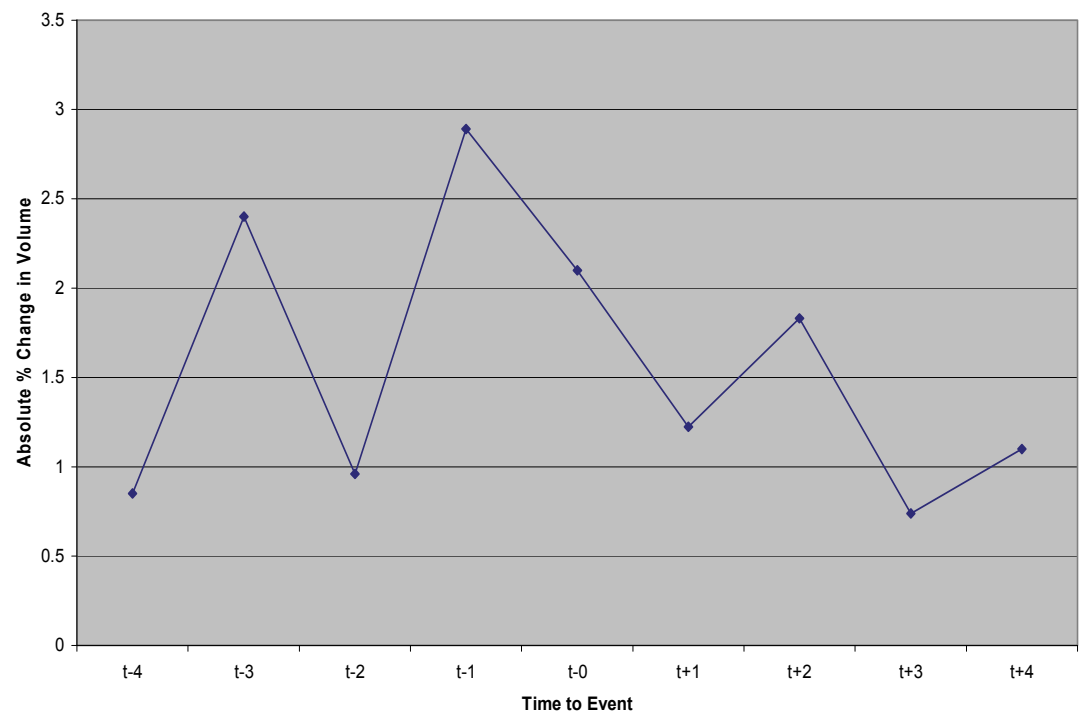

Trading before an event takes place does not necessarily render a market inefficient. Inefficiency only arises when market prices do not adjust to incorporate trading information. Next, we display absolute changes in price, and one observes that prices do begin to adjust a day prior to the event. However, the greatest adjustment takes place approximately three days after the news is released, when the second jump in trading volume takes place. 
TABLE 2

ABSOLUTE CHANGE IN PRICE, YEARS 1998-2008, N=63

\begin{tabular}{|l|l|l|l|l|}
\hline Variable & $\underline{\text { Mean }}$ & $\underline{\text { Std. Deviation }}$ & $\underline{\text { Min }}$ & $\underline{\text { Max }}$ \\
\hline$\underline{\text { Pricet-5 }}$ & $\underline{1.78}$ & $\underline{2.48}$ & $\underline{0}$ & $\underline{13.14}$ \\
\hline Pricet-4 & $\underline{1.50}$ & $\underline{1.99}$ & $\underline{0}$ & $\underline{10.48}$ \\
\hline Pricet-3 & $\underline{1.48}$ & $\underline{2.04}$ & $\underline{0}$ & $\underline{12}$ \\
\hline Pricet-2 & $\underline{1.70}$ & $\underline{2.18}$ & $\underline{0}$ & $\underline{9.26}$ \\
\hline Pricet-1 & $\underline{1.82}$ & $\underline{4.00}$ & $\underline{0}$ & $\underline{28.45}$ \\
\hline$\underline{\text { Pricet }=0}$ & $\underline{1.55}$ & $\underline{2.78}$ & $\underline{0}$ & $\underline{18.10}$ \\
\hline Pricet+1 & $\underline{1.91}$ & $\underline{2.27}$ & $\underline{0}$ & $\underline{9.38}$ \\
\hline Pricet+2 & $\underline{1.65}$ & $\underline{1.80}$ & $\underline{0}$ & $\underline{8.42}$ \\
\hline$\underline{\text { Pricet+3 }}$ & $\underline{1.29}$ & $\underline{1.41}$ & $\underline{0}$ & $\underline{6.67}$ \\
\hline$\underline{\text { Pricet+4 }}$ & $\underline{1.84}$ & $\underline{3.24}$ & $\underline{0}$ & $\underline{16.95}$ \\
\hline$\underline{\text { Pricet+5 }}$ & $\underline{1.87}$ & $\underline{2.80}$ & $\underline{0}$ & $\underline{16.28}$ \\
\hline
\end{tabular}

In Figure 3, the greatest change in price takes place between days three and four after an event. Yet, prices begin to adjust in line with the large change in trading volume, a day prior to the event.

FIGURE 3

ABSOLUTE CHANGE IN PRICE AROUND EVENT DATE

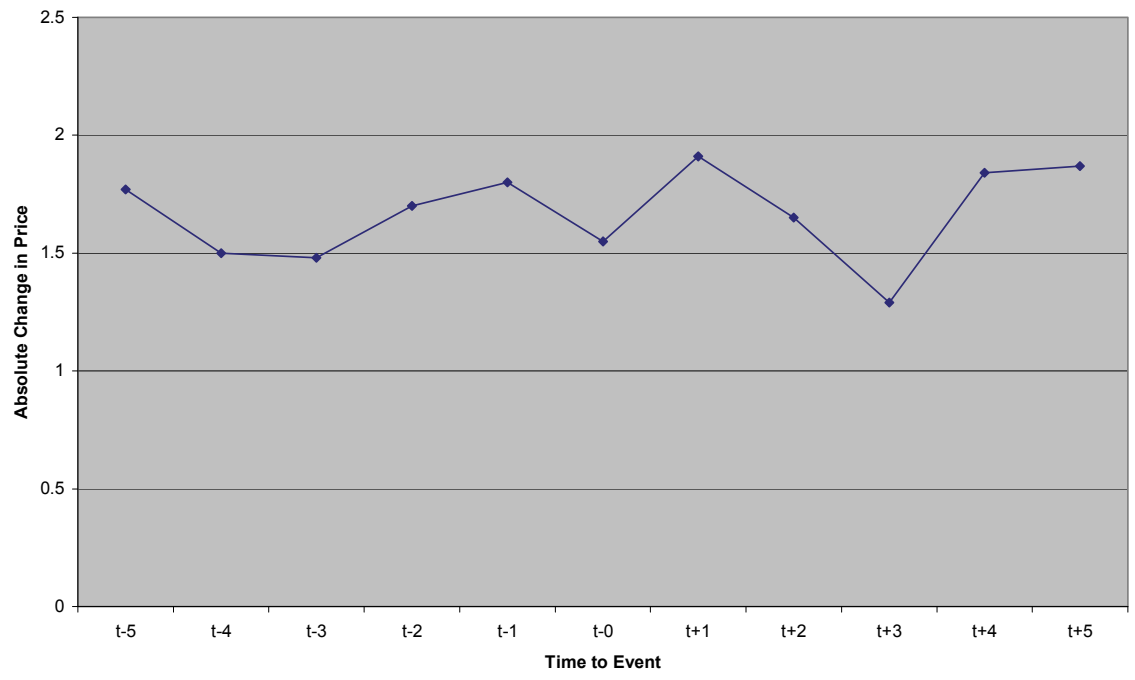

Apparently, the trading that takes place after the event has a greater impact on price than the trading based on inside information that takes place before an event. However, though trading does occur before a news event, prices catch up fairly quickly, and like most firms in the U.S. take approximately five days after an event to adjust (Dedman, 2004). Our evidence, therefore, points towards a market that is semistrong efficient. 


\section{CONCLUSION}

In conclusion, employing a small sample of firms from the public venture capital industry, we explored whether news leakage may lead to share trading before an important news event. The reason we suspected this may be the case is due to the high level of insider and institutional ownership in this industry (see Rozen 2015). We expected many owners to therefore possess information upon which they may choose to trade shares. While trading may be legal provided certain stipulations are met, the effect of news leakage may lead to an inefficient capital market. Therefore, using event studies, we examined how quickly the market adjusted after a news event. We found that news is indeed leaked before an important news event, however prices adjust within several days after the news event rendering the market semistrong efficient.

\section{ENDNOTES}

1. https://www.seclaw.com/insider-trading/

2. Much of the discussion related to the institutional setting of the public venture capital industry was previously published by the author in a related article. Please see: Rozen, H. (2015). The Relationship Between Firm Performance and the Market's Trust in Security Estimates: Evidence from the Public Venture Capital Industry. Journal of Accounting and Finance, 15, (4), 183-195.

3. In other countries where corporate tax laws are different, such as Australia, Canada, India, Israel, and the United Kingdom, a much greater percentage of VC's are publicly traded.

\section{REFERENCES}

Ball, R. (1978). Anomalies in Relationships Between Securities' Yields and Yield-Surrogates. Journal of Financial Economics, 6, 103-126.

Ball, R. (1994). On the Development, Accomplishments and Limitations of the Theory of Stock Market Efficiency. Managerial Finance, 20(2-3), 3-48.

Ball, R. (1995). The Theory of Stock Market Efficiency: Accomplishments and Limitations. Journal of Applied Corporate Finance, 8, 4-17.

Ball, R. (2009). The Global Financial Crisis and the Efficient Market Hypothesis: What Have we Learned? Journal of Applied Corporate Finance, 21(4), 8-16.

Ball, R. \& Brown, P. (1968). An Empirical Evaluation of Accounting Income Numbers. Journal of Accounting Research, 6, 189-178.

Barry, C.B. (1994). New Directions in Research on Venture Capital Finance. Financial Management, 23(3), 3-15.

Brophy, D.J. \& Guthner, M.W. (1988). Publicly Traded Venture Capital Funds: Implications for Institutional "Fund of Funds" Investors. Journal of Business Venturing, 3, 187-206.

Brown, S.J. \& Warner, J.B. (1985). Using Daily Stock Returns: The Case of Event Studies. Journal of Financial Economics, 14, 3-31.

Chan, K.C., Gup, B.E., \& Pan, M.S. (1997). International Stock Market Efficiency and Integration: A Study of Eighteen Nations. Journal of Business Finance \& Accounting, 24(6), 803-813.

Chang, S. \& Suk, D.Y. (1998). Stock Prices and the Secondary Dissemination of Information: The Wall Street Journal's “Insider Trading Spotlight” Column. The Financial Review, 33(3), 115-128.

Charest, G. (1978). Dividend Information, Stock Returns and Market Efficiency. Journal of Financial Economics, 6, 297-330.

Cumming, D. \& Johan, S. (2008). Information Asymmetries, Agency Costs and Venture Capital Exit Outcomes. International Journal of Entrepreneurial Finance, 10(3), 197-231.

Dedman, E. (2004). Discussion of Reactions of the London Stock Exchange to Company Trading Statement Announcements. Journal of Business Finance \& Accounting, 31(1-2), 37-47. 
Fama, E.F. (1970). Efficient Capital Markets: A Review of Theory and Empirical Work. Journal of Finance, 25, 283-417.

Fama, E.F. (1998). Market Efficiency, Long Term Returns, and Behavioral Finance. Journal of Financial Economics, 49, 283-306.

Fama, E.F., Fisher, L., Jensen, M., \& Roll, R. (1969). The Adjustment of Stock Prices to New Information. International Economic Review, 10, 1-21.

Gompers, P.A. (1994). The Rise and Fall of Venture Capital. Business and Economic History, 23(2), 126.

Gompers, P.A. (1995). Optimal Investment, Monitoring, and the Staging of Venture Capital. Journal of Finance, 50(5), 1461-1489.

Lerner, J. \& Watson, B. (2008). The Public Venture Capital Challenge: the Australian Case. International Journal of Entrepreneurial Finance, 10(1), 1-20.

Lo, A.W. (2004). The Adaptive Markets Hypothesis: Market Efficiency from an Evolutionary Perspective. Journal of Portfolio Management, 30, 15-29.

Malkiel, B.G. (1973). A Random Walk Down Wall Street, New York: W.W. Norton \& Co.

Malkiel, B.G. (2003). The Efficient Market Hypothesis and Its Critics. Journal of Economic Perspectives, $17,59-82$.

McWilliams, A. \& Siegel, D.S. (1997). Event Studies in Management Research: Theoretical and Empirical Issues. The Academy of Management Journal, 40, 626-657.

Persons, O. (1997). SEC's Insider Trading Enforcements and Target Firms' Stock Values. Journal of Business Research, 39, 187-194.

Rozen, H. (2015). The Relationship Between Firm Performance and the Market's Trust in Security Estimates: Evidence from the Public Venture Capital Industry. Journal of Accounting and Finance, 15(4), 183-195.

Schwert, G. W. (2003). Anomalies and Market Efficiency. Handbook of the Economics of Finance, Volume 1B, Financial Markets and Asset Pricing, 21, 937-972.

T'oth, B. \& Kert'esz, J. (2006). Increasing market efficiency: Evolution of cross-correlations of stock returns. Physica A, 360(2), 505-515.

Watts, R.L. (1978). Systematic 'Abnormal' Returns After Quarterly Earnings Announcements. Journal of Financial Economics, 6, 127-150.

\section{APPENDIX}

\section{The Venture Capital Firm, Private vs. Public}

$\underline{\text { Private }} \quad \underline{\text { Public }}$

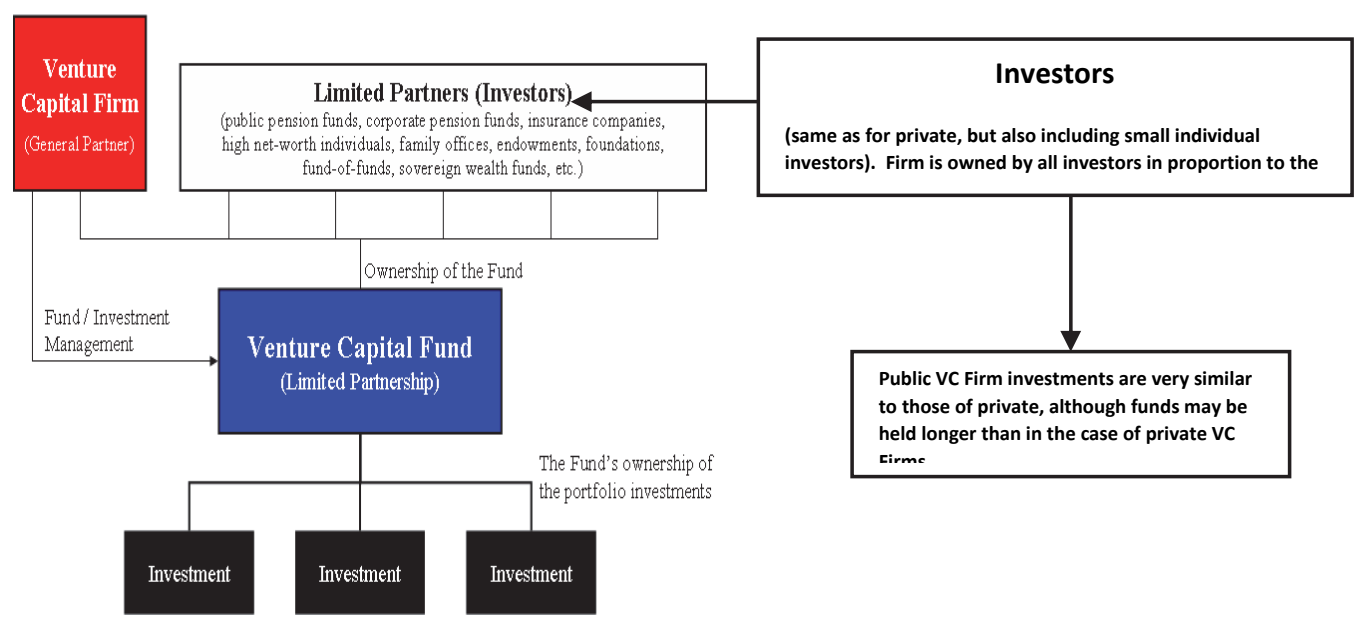

106 Journal of Applied Business and Economics Vol. 21(3) 2019 